\title{
Castable cements to prevent corrosion of metals in molten salts
}

\author{
J. C. Gomez ${ }^{1, *}$, and E. Morton ${ }^{1}$ \\ ${ }^{1}$ National Renewable Energy Laboratory, 15013 Denver West Parkway, Golden, CO 80401 \\ *Corresponding author: judith.gomez@ nrel.gov
}

\begin{abstract}
Castable cements on metals form a protective barrier that is able to prevent permeation of molten salts towards metallic surfaces. Silica-based castable cements are capable of protecting containment metallic alloys from the corrosive attack of molten chlorides at temperatures as high as $650^{\circ} \mathrm{C}$. Boron nitride $(\mathrm{BN})$ blocking the pores in the cured cement prevents permeation of the molten chloride towards the metal surface. The cements tested are not chemically stable in molten carbonates, because the bonding components dissolved into molten carbonates salt. The corrosion rate is $7.72 \pm 0.32 \mathrm{~mm} /$ year for bare stainless steel 347 in molten eutectic $\mathrm{NaCl}-65.58$ $\mathrm{wt} \% \mathrm{LiCl}$ at $650^{\circ} \mathrm{C}$, which is the baseline used for determining how well the cement protects the metallic surfaces from corrosion. In particular metal fully encapsulated with Aremco 645-N with pores filled with boron nitride immersed in molten eutectic $\mathrm{NaCl}-65.58 \mathrm{wt} \% \mathrm{LiCl}$ at $650^{\circ} \mathrm{C}$ shows a corrosion rate of $9 \mathrm{E}-04 \mathrm{~mm} /$ year. The present study gives initial corrosion rates. Longterm tests are required to determine if Aremco 645-N with BN coating on metal has long term chemical stability for blocking salt permeation through coating pores.
\end{abstract}

Keywords - concentrating solar power; heat transfer fluid; thermal energy storage; molten salts; ceramics; corrosion.

\section{Introduction}

The U.S. Department of Energy's (DOE's) SunShot initiative focuses on developing solar power technologies to become cost-competitive with other nonrenewable sources of electricity by the year 2020 [1]. Concentrating solar power (CSP) technology is one technology within DOE's portfolio that can achieve this initiative by using advanced heat transfer fluids (HTFs) and thermal energy storage (TES). TES allows the thermal energy generated by the sun during the day to be stored and transferred to create electricity during the night [2]. The National 
Renewable Energy Laboratory (NREL) is working to improve this storage technology to increase the efficiency of CSP and reduce costs in order to reach DOE's goal of $6 \notin / \mathrm{kWh}$.

NREL has recommended some molten chlorides and molten carbonates as HTFs and TES candidates for high temperature applications because of their cost, high thermal stability, and relatively high heat capacity. However, these salts are highly corrosive and can degrade piping and containment materials [3]. To achieve the SunShot initiative targets, materials with high corrosion resistance need to be developed and tested.

Ceramics has been used in previous research to withstand molten salt corrosion and has demonstrated positive results. A commercial ceramic named Cofalit was studied as a possible filler material in a molten salt thermocline storage system [4]. Inertised asbestos-containing waste was tested for its compatibility with molten salts for use in combining the sensible heat and phase-change material stages of CSP [5]. An yttria-zirconia top coat was tested for protection of superalloys for molten salt corrosion in lithium molten salts [6]. Also, silicon nitride, mullite, and cordierite had molten salt corrosion rates of less than $0.1 \mathrm{~mm} / \mathrm{year}$ for use in pyrochemical reprocessing [7]. Boron nitride $(\mathrm{BN})$ has also been found to provide protection against corrosive salts. Nitrided nickel-boron coatings were found to improve nickel-boron coating properties and have better corrosion resistance than untreated coatings [8]. Zirconium boron nitride coatings on carbon steel substrates performed better than zirconium boride coatings in a corrosive environment [9].

The Thermal Systems Group at NREL is proposing the use of castable ceramic cements to protect containment materials from the attack of molten salts at high temperatures. By using castable cements the exposed surfaces can be repaired and the plant down time can be minimized. Examples of this approach are employed in the metal industry production in which castable refractory cements are used to protect metal containments and refractory bricks inside the furnaces that contain molten slag/metal and/or molten glass.

Silica and silicate-based castable cements were evaluated in molten salts from $600^{\circ}$ to $750^{\circ} \mathrm{C}$. The molten salts used were eutectics: $\mathrm{K}_{2} \mathrm{CO}_{3}-\mathrm{Na}_{2} \mathrm{CO}_{3}, \mathrm{~K}_{2} \mathrm{CO}_{3}-\mathrm{Na}_{2} \mathrm{CO}_{3}-\mathrm{Li}_{2} \mathrm{CO}_{3}, \mathrm{NaCl}-$ $\mathrm{LiCl}$, and $\mathrm{NaCl}-\mathrm{KCl}$. The chemical resistance of the cured cements was first determined by using immersion techniques. Those compositions that showed chemical stability were further evaluated for salt permeation using electrochemical techniques. The permeability of the cements 
by the molten salts was studied by comparing corrosion rates of bare alloys with those encapsulated alloys using the castable refractory cements. Cylinders of stainless steel 347 (SS347) were encapsulated using a variety of cement and spray/paint combinations to determine the encapsulation configuration that provided the best protective conditions.

\section{Materials and methods}

\subsection{Preparation of salt mixture}

Table 1 shows the composition of each molten salt tested, its melting/eutectic temperature, and the tested temperature. The salt mixtures were prepared using ACS grade anhydrous salts, each with a purity greater than 99 wt.\%, as received from Alfa Aesar. The single salts were placed in a drying oven (DK-42, American Scientific Products) at $120^{\circ} \mathrm{C}$ in air for at least 48 hours to ensure low moisture content. The salts were weighed and mixed to the proper ratio in $125-\mathrm{g}$ batches. The salts were then placed in an alumina crucible because this material has been shown to be chemically stable against the majority of the molten salts. The crucible containing the salt mixture was kept in a vacuum furnace at $120^{\circ} \mathrm{C}$ for 24 hours and then transferred to a muffle furnace (Vulcan 3-1750), heated and held at $300^{\circ} \mathrm{C}$ for three hours. A pre-melting procedure was used in which the salt mixture was exposed for one hour to a temperature of $100^{\circ} \mathrm{C}$ above the highest melting point of the single components; this method yielded homogeneous eutectic compositions. To avoid moisture absorption after cooling, the pre-melted and solidified salt mixture was stored at $120^{\circ} \mathrm{C}$ in the vacuum furnace until needed for testing. Since the CSP plants cannot pursue very complicated and expensive mixing and melting procedures of the salts, the salt preparation followed here did not consider any further purification of the mixture.

Table 1. Eutectic composition in mass percentage (wt.\%) of the molten salts. Melting/eutectic temperature $\left(\mathrm{T}_{\mathrm{e}}\right)$ and tested temperatures $\left(\mathrm{T}_{\mathrm{t}}\right)$.

\begin{tabular}{llcc}
\hline \multicolumn{1}{c}{ Name } & \multicolumn{1}{c}{ Composition, wt.\% } & $\begin{array}{c}\mathbf{T}_{\mathbf{e}}, \\
{ }^{\circ} \mathbf{C}\end{array}$ & $\begin{array}{c}\mathbf{T}_{\mathbf{t}}, \\
{ }^{\circ} \mathbf{C}\end{array}$ \\
\hline $\mathrm{KNaLi}^{-\mathrm{CO}_{3}}$ & $\mathrm{~K}_{2} \mathrm{CO}_{3}-33.39 \mathrm{wt} \% \mathrm{Na}_{2} \mathrm{CO}_{3}-32.14 \mathrm{wt} \% \mathrm{Li}_{2} \mathrm{CO}_{3}$ & 398 & 600 \\
$\mathrm{KNa}-\mathrm{CO}_{3}$ & $\mathrm{~K}_{2} \mathrm{CO}_{3}-53.82 \mathrm{wt} \% \mathrm{Na}_{2} \mathrm{CO}_{3}$ & 709 & 750 \\
$\mathrm{NaLi}-\mathrm{Cl}$ & $\mathrm{NaCl}-65.58 \mathrm{wt} \% \mathrm{LiCl}$ & 554 & 650 \\
$\mathrm{NaK}-\mathrm{Cl}$ & $\mathrm{NaCl}-55.47 \mathrm{wt} \% \mathrm{KCl}$ & 657 & 700 \\
\hline
\end{tabular}

\subsection{Chemical compatibility of cements}

The chemical compatibility of four different cements was tested in several molten salt mixtures. Each cement configuration was tested by immersing the fully cured cement in the molten salt 
contained in an alumina crucible. The chemical composition of the castable refractory cements is shown in Table 2. Each cement was prepared following the supplier's instructions. Water or liquid silicate (for Sauereisen \#31) was employed as the liquid binder. For chemical stability testing, the cement samples were prepared and cast in a piece of plastic tubing that was used as a mold. A $1 / 8$ " diameter alumina tube was inserted into the fresh cement to allow holding it and immersing it into the molten salt for chemical testing. The curing process was performed at room temperature for 20 hours to develop the cement's green strength. The plastic tubing was then removed to complete the curing process in a muffle furnace up to $121^{\circ} \mathrm{C}$. Parameters of the curing process are shown in Table 3.

Table 2. Chemical composition of castable ceramic refractory cements provided by the supplier.

\begin{tabular}{cl}
\hline Cement & \multicolumn{1}{c}{ Composition, wt.\% } \\
\hline & Fused silica: $40-75$ \\
Aremco & Magnesium phosphate mono basic: $5-20$ \\
$645-\mathrm{N}$ & Zirconium silicate: $5-10$ \\
& Magnesium oxide: $5-20$ \\
& Silica crystalline: $<0.5$ \\
& Zirconium silicate: $<68-78$ \\
Sauereisen & Magnesium phosphate mono basic: $<11-18$ \\
$\# 8$ & Magnesium oxide: $<10-15$ \\
& Boric acid: $<2$ \\
\hline \multirow{2}{*}{ Sauereisen } & Silica crystalline: $<1$ \\
$\# 31$ & Silica crystalline: $<90$ \\
& Sodium silica fluoride $<15$ \\
\hline Sauereisen & Clay: $<5$ \\
$\# 76$ & Silica crystalline $<80$ \\
& Calcium aluminate $<40$ \\
\hline
\end{tabular}

Table 3. Parameters of the cement curing process (provided by Sauereisen Corporation).

\begin{tabular}{cc}
\hline Time, hours & Temperature, ${ }^{\circ} \mathbf{C}$ \\
\hline $18-24$ & room temperature \\
$8-12$ & 66 \\
4 & 82 \\
4 & 93 \\
4 & 105 \\
4 & 121 \\
$38^{\circ} \mathrm{C} / \mathrm{h}$ & up to the testing \\
& temperature \\
\hline
\end{tabular}

After curing, some pieces were painted or sprayed with a ceramic compound to block the porosity. The chemical composition of the paints and aerosols used to seal the cement porosity 
can be found in Table 4. A picture of a consolidated piece of cured refractory cement employed for chemical testing is shown in Figure 1.

Table 4. Paints and aerosol chemical compositions.

\begin{tabular}{ccl}
$\begin{array}{c}\text { Product } \\
\text { Name }\end{array}$ & $\begin{array}{c}\text { Company } \\
\text { Name }\end{array}$ & \multicolumn{1}{c}{ Composition, wt.\% } \\
\hline & ZYP & BN: $15-20$ \\
& Ethanol: $15-20$ \\
BN aerosol & Coatings, & 2-Propanone: $30-35$ \\
& Inc. & $\begin{array}{l}\text { Propane: } 10-15 \\
\text { Butane: } 10-15\end{array}$ \\
\hline Ceramabind & Aremco & Potassium Silicate: 30 \\
643-1 paint & Water: 70 \\
\hline & & BN: 97 \\
BN paint & Aremco & Magnesia: 1 \\
& & Silica: 2 \\
& Carbon binder for sintering: $<2$ \\
\hline
\end{tabular}

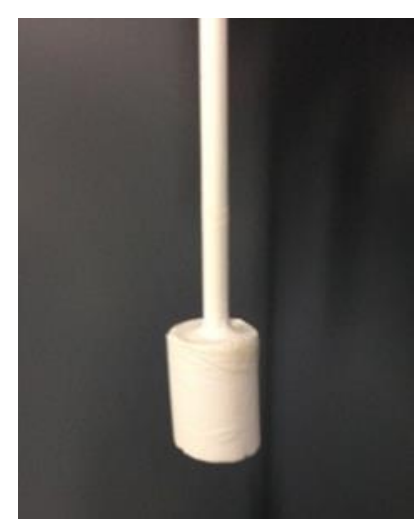

Fig. 1. Consolidated piece of cured refractory cement employed for chemical testing.

The cured cement and the premelted salt mixture were placed in a controlled atmosphere furnace (see Figure 2) under ultra high purity (UHP) nitrogen (99.999\% purity). A slow heating ramp of $38^{\circ} \mathrm{C} / \mathrm{h}$ up to the testing temperature was employed to avoid any fracture of the cement during heating. A total heating process of about 20 hours under controlled atmosphere was employed for each test to allow thermal and chemical equilibration of the system with the nitrogen atmosphere. 


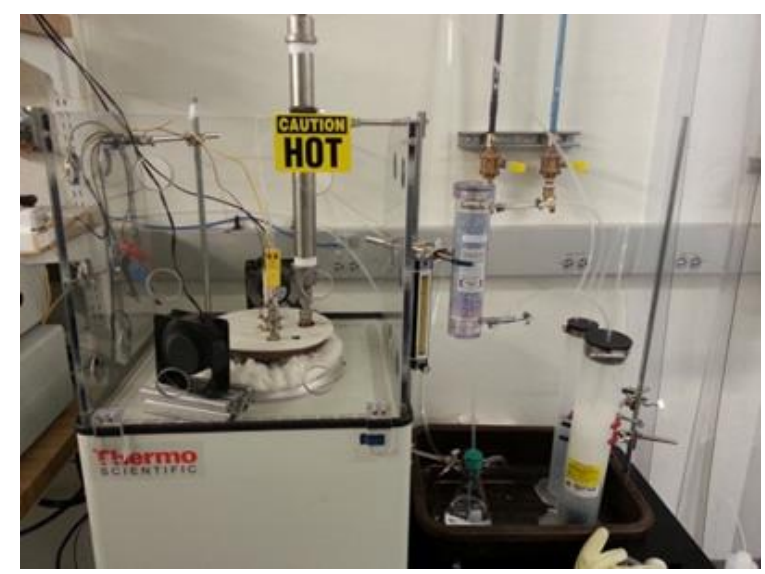

Fig. 2. Molten salt corrosion electrochemical system with the off-gas treatment.

After one hour of thermal equilibration at the testing temperature, the fully cured cement was immersed into the molten salt for two hours. The dissolved elements from the best-performing cement configuration were analyzed from molten salt samples before and after degradation using inductively coupled plasma-mass spectroscopy (ICP-MS). For CSP plants, the best-performing cement configuration will be the one that mitigates the corrosion of metallic surfaces to values below $20 \mu \mathrm{m} /$ year.

\subsection{Electrochemical corrosion testing for salt permeability determination}

The cements (Table 2) that passed the chemical stability test were tested using electrochemical techniques with metallic samples (bare and encapsulated) to determine the best cement configuration that stopped the salt permeability through the cement. The elemental composition of tested SS347 is shown in Table 5.

Table 5. Elemental composition of stainless steel 347 (SS347).

\begin{tabular}{ccccccc}
\hline \multicolumn{7}{c}{ Elemental Composition, wt.\% } \\
$\mathbf{F e}$ & $\mathbf{N i}$ & $\mathbf{C r}$ & $\mathbf{C o}$ & $\mathbf{M n}$ & $\mathbf{S i}$ & $\mathbf{C}$ \\
\hline$\sim 70.03$ & 9.62 & 17.67 & 0.2 & 1.66 & 0.77 & 0.051 \\
\hline
\end{tabular}

Corrosion rates of SS347 were calculated using electrochemical techniques and compared among different encapsulation configurations. Corrosion values were used to determine what encapsulation configuration will best be able to protect the alloys from further corrosion. Electrochemical techniques are very fast and corrosion results can be obtained after a few minutes of testing. To compare corrosion rates of different materials the data is normalized per unit area. Those cement configurations that provided the same corrosion rate in the encapsulated 
alloys as compared to the bare alloys demonstrated that the salt was not able to permeate and thus attack the metal surface covered by the cement.

The molten salt corrosion electrochemical system, shown in Figure 2, was used to determine the corrosion rates of bare and encapsulated alloys using electrochemical techniques. The potential of the sample or working electrode (WE) was measured by a potentiostat (AUTOLABPGSTAT302N) with respect to the reference electrode (RE). Platinum wire of 0.5 -mm diameter was used as the pseudo-RE. Pt-mesh spot-welded to Pt-wire was used as the counter electrode (CE). Platinum has been recommended by several researchers for high temperature molten salt corrosion evaluations using electrochemical techniques [10-14]. The potential of the Pt pseudo$\mathrm{RE}$ is not known. Based on corrosion literature this material reaches chemical and electrical stability with chloride molten salts after about 45 to 60 minutes after immersion.

Cylindrical samples of SS347 were polished with SiC sand paper up to 1200 grit, washed with deionized water, and dried with acetone. The electrical connection of the sample/WE was obtained using a $0.5-\mathrm{mm}$ diameter nickel-chromium wire spot-welded to the top portion of the WE. The wires were electrically insulated using $1 / 8$ " alumina tubes sealed with refractory silicabased cement.

To measure the corrosion of the alloys electrochemical techniques such as open circuit potential (OCP) followed by potentiodynamic polarization sweep (PPS) were employed. OCP is the equilibrium potential for an undisturbed system (no external potential applied) that exists naturally within a corrosion system [14-18]. When a metal is immersed in an electrolyte (molten salt), the ions present in the melt are rearranged and establish an electrical potential (E) at the metal-electrolyte interface. Because molten salts are complex and temperature gradients in the melt can modify physical properties in narrow physical spaces, a dynamic equilibrium is established at this interface. In order to accurately evaluate corrosion, a steady state needs to be reached before recording corrosion data. To determine this state, potentials are recorded as a function of time until certain stability is reached which is usually for $\mathrm{dE} / \mathrm{dt} \leq 100 \mu \mathrm{V} / \mathrm{s}$.

The PPS technique sweeps potentials (in V) and records current (A). To normalize the current, the immersed metallic area of the sample (in $\mathrm{cm}^{2}$ ) is used to determine the current density $\left(\mathrm{A} / \mathrm{cm}^{2}\right)$. The PPS plots, as the one shown in Fig. 3, are represented as applied potential (versus Pt-pseudo-RE) as a function of measured current density. These plots are used to determine the 
cathodic and anodic Tafel slopes which are usually found in the linear portions between -250 $\mathrm{mV}$ and $+250 \mathrm{mV}$ relative to the OCP of the sample or working electrode (WE). At this voltage range near the $\mathrm{OCP}$, pure cathodic and anodic reactions are established at the cathodic $(\mathrm{E}<$ OCP) and anodic (E > OCP) branches respectively [18].

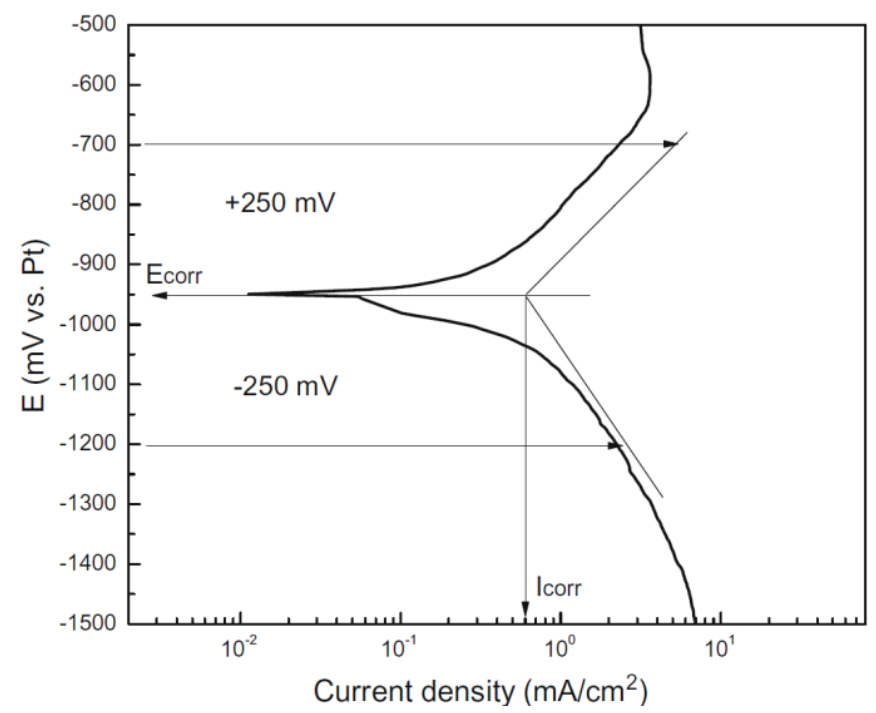

Fig. 3. Scheme showing the procedure to calculate Icorr and Tafel slopes [18].

The Tafel slopes' intersection gives the value of the corrosion current density $\left(I_{\text {corr }}\right)$ and corrosion potential $\left(E_{c o r r}\right)$. The corrosion rates are calculated using the Stern-Geary equation through Faraday's law [16,18]:

$$
C R=\frac{I_{\text {corr }} \cdot K \cdot E W}{\rho}
$$

where CR is the corrosion rate (mm/year), $\mathrm{K}$ is a constant equal to $3272[\mathrm{~mm} /(\mathrm{A} \cdot \mathrm{cm} \cdot$ year)], EW is the equivalent weight of the alloy $(\mathrm{g} / \mathrm{mole}-\mathrm{e})$, and $\rho$ is the alloy density $\left(\mathrm{g} / \mathrm{cm}^{3}\right)$.

To perform the corrosion evaluation the sample/WE and the premelted salt mixture, contained in the alumina crucible, were placed in the corrosion cell (see Figure 2) under a UHP-nitrogen atmosphere for at least 20 hours during heating. The electrochemical cell employed for corrosion rate determination uses a three-electrode arrangement (sample/WE, RE, and CE). A drawing and a picture of the three-electrode arrangement inside of the electrochemical cell is shown in Figure 4. After reaching one hour of thermal stability at the testing temperature, the Pt-pseudo-RE and the Pt-CE were immersed and allowed to stabilize during $60 \mathrm{~min}$ before immersing the sample/WE [10-14]. The sample/WE was immersed 3-4 $\mathrm{mm}$ in the molten salt after RE and CE 
stabilization time. The sample was allowed to reach voltage stability, or OCP, before the PPS test was conducted. Then the polarization sweep was applied from $-0.4 \mathrm{~V}$ to $+0.5 \mathrm{~V}$ at $1 \mathrm{mV} / \mathrm{s}$.
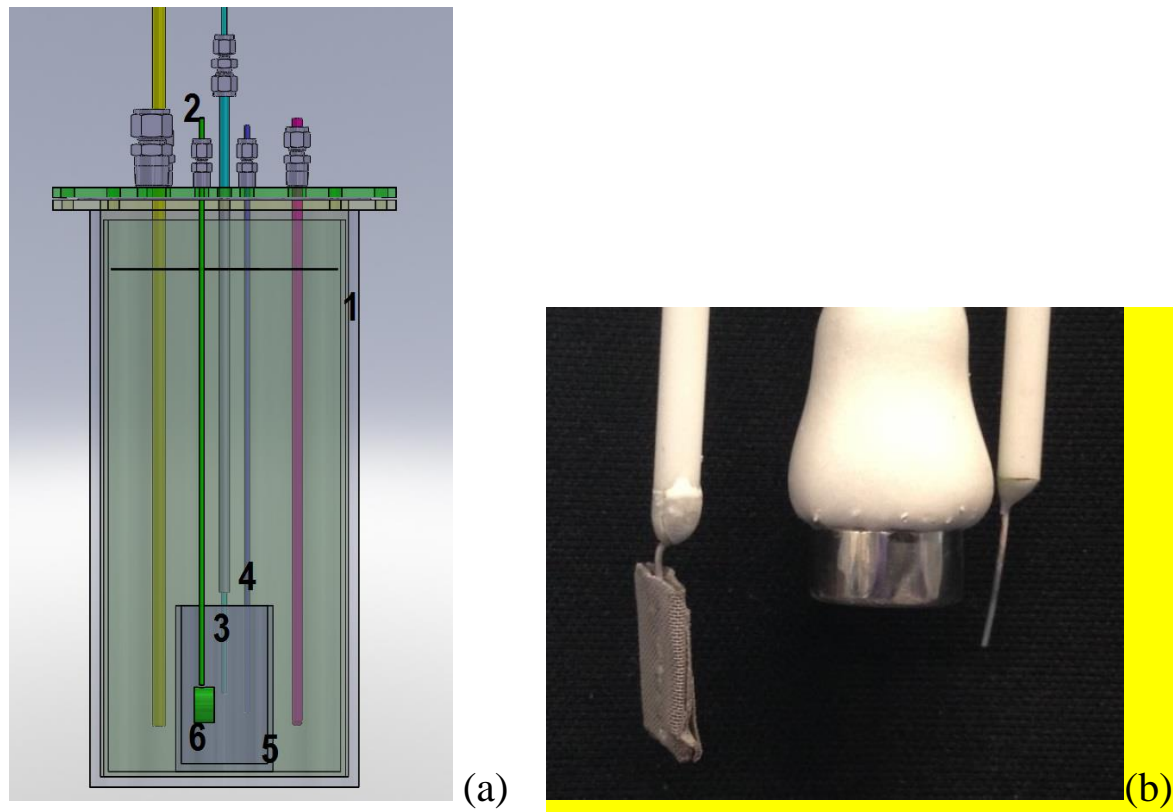

Fig. 4. (a) Drawing of the electrochemical cell with the three-electrode arrangement. 1: stainless steel 316 chamber with quartz lining; 2: working electrode or sample electrical connector; 3: Ptpseudo reference electrode (RE); 4: platinum counter electrode (CE); 5: alumina crucible containing molten salts; 6: encapsulated sample or working electrode (WE), and (b) Picture of the three-electrode arrangement (left to right: CE, WE, and RE).

The metallic samples were encapsulated using a variety of cement and spray/paint combinations (from Tables 2 and 4) to determine the encapsulation configuration that provided the best protective conditions. A picture of an encapsulated SS347 cylinder is shown in Figure 5. The corrosion rate values were used as a baseline to determine what cement/film configuration provided the same corrosion rate for the controlled area exposed to the molten salt. If the cement allowed the permeation of the molten salt, the corrosion rate increased.

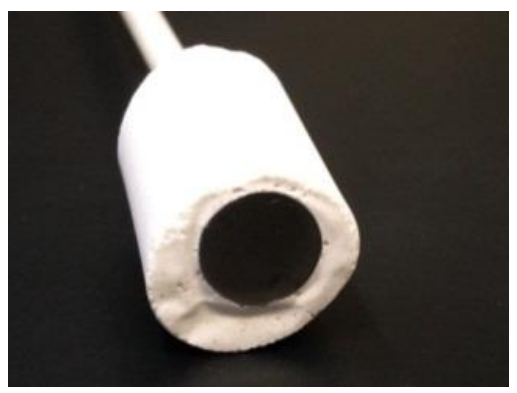

Fig. 5. Encapsulated stainless steel 347 (SS347) cylinder. 


\subsection{Thermodynamic modeling of degradation}

HSC Chemistry software [19] is a program that calculates chemical states of species in thermodynamic equilibria using a thermochemical database which contains enthalpy $(H)$, entropy (S) and heat capacity (Cp) data for more than 28000 chemical species. The HSC method does not take into account chemical kinetics. HSC Chemistry Software was used to characterize chemical compatibility of the tested ceramics with the molten salt by determining the Gibbs Free Energy minimization. Reactions between the ceramics and the molten chlorides were considered. Probable reactions were identified using the "Reaction Equations" module using the equilibrium composition data as a function of temperature from $500^{\circ} \mathrm{C}$ to $1,000^{\circ} \mathrm{C}$.

\section{Results and discussion}

\subsection{Chemical compatibility of cements}

All the cement configurations tested in $\mathrm{KNa}-\mathrm{CO}_{3}$ at $750^{\circ} \mathrm{C}$ and $\mathrm{KNaLi}-\mathrm{CO}_{3}$ at $600^{\circ} \mathrm{C}$ were not chemically stable. Immediately after immersion, the cements decomposed and produced a large amount of gas. After opening the cell it was observed that the portion of cement immersed into the molten carbonate was completely dissolved. Sauereisen \#8 was lightly dissolved in $\mathrm{KNaLi}$ $\mathrm{CO}_{3}$. Another test was performed with this cement in a vapor of $\mathrm{KNaLi}-\mathrm{CO}_{3}$ over the course of two hours. It showed some chemical stability under these conditions. The cements showed a better chemical behavior in the chloride molten salt mixtures at $650^{\circ}$ and $700^{\circ} \mathrm{C}$. Aremco $645-\mathrm{N}$ was found to be the most chemically compatible with the molten $\mathrm{NaLi}-\mathrm{Cl}$ mixture. Sauereisen \#31 contained several cracks after being tested. Sauereisen \#76 appeared very porous after curing and began to crumble; therefore, it was not tested in the molten chloride mixtures. Sauereisen \#8 tested in $\mathrm{NaK}-\mathrm{Cl}$ at $700^{\circ} \mathrm{C}$ showed very good chemical stability. The aggregate of these cements are silica or silicate compounds, which are in general very stable when in contact with molten carbonates and molten chlorides. The chemical stability of the cements in the molten salts is based on their binder phase. The most chemically stable configurations in the molten chloride were Aremco 645-N with and without BN (paint or spray).

Aremco 645-N cement performed better than the Sauereisen cements because of its chemical composition. Sauereisen \#8 has a similar composition as Aremco 645-N. Both Aremco 645-N and Sauereisen \#8 have magnesium phosphate mono basic binders. However, it seems that the 
fused silica filler of the Aremco $645-\mathrm{N}$ worked better than the zirconium silicate filler of Sauereisen \#8.

The chemical dissolution of Aremco 645-N with BN spray was evaluated using ICP-MS of the molten salt before and after degradation. The chemical composition of the fresh salt (before cement dissolution) was used as the baseline and it was subtracted from the chemical composition of the salt after degradation to obtain the composition of the elements dissolved from the cement (see Table 6). The data were adjusted to the total mass of salt employed and normalized to the surface exposed to the molten salt. Among the elements analyzed, magnesium shows the highest concentration $\left(3.61 \mathrm{ppm} / \mathrm{cm}^{2}\right)$ followed by boron $\left(1.00 \mathrm{ppm} / \mathrm{cm}^{2}\right)$. Magnesium is present as magnesium phosphate mono basic and magnesium oxide in Aremco 645-N cement (see Table 2). Boron probably comes from the BN film used to block the porosity of the cement. These small concentrations of dissolved elements show a little degradation of the cement/BN configuration. It is recommended that long-term degradation tests be performed to determine the dissolution kinetics of the cements and when the stabilization of dissolved elements is reached. To determine this stabilization, the area to molten salt volume ratio needs to be controlled to simulate real CSP plant operational conditions.

Table 6. ICP-MS chemical analysis of dissolved elements from refractory cement (silica base sprayed with $\mathrm{BN}$ ) in $124 \mathrm{~g}$ of eutectic $\mathrm{NaCl}-\mathrm{LiCl}$ at $650^{\circ} \mathrm{C}$ for two hours. Results are normalized to exposed area. Values are reported as average and standard deviation for three sets of data.

\begin{tabular}{|c|c|c|c|c|c|c|c|c|c|c|c|c|}
\hline Elements & Al & B & $\mathrm{Ca}$ & Co & $\mathrm{Cr}$ & $\mathrm{Cu}$ & $\mathbf{F e}$ & Mg & Mn & Mo & $\mathbf{N i}$ & V \\
\hline $\begin{array}{c}\text { Normalized } \\
\text { Composition } \\
\left(\mathrm{ppm} / \mathrm{cm}^{2}\right)\end{array}$ & $\begin{array}{c}0.07 \\
\pm \\
0.00\end{array}$ & $\begin{array}{c}1.00 \\
\pm \\
0.01\end{array}$ & $\begin{array}{c}\mathrm{BDL} \\
*\end{array}$ & $\begin{array}{c}0.09 \\
\pm \\
0.00\end{array}$ & $\begin{array}{c}0.08 \\
\pm \\
0.00\end{array}$ & $\begin{array}{c}0.22 \\
\pm \\
0.01\end{array}$ & $\begin{array}{c}0.27 \\
\pm \\
0.00\end{array}$ & $\begin{array}{c}3.61 \\
\pm \\
0.05\end{array}$ & $\begin{array}{c}0.10 \\
\pm \\
0.00\end{array}$ & $\begin{array}{c}\mathrm{BDL} \\
*\end{array}$ & $\begin{array}{c}\text { BDL } \\
*\end{array}$ & $\begin{array}{c}0.07 \pm \\
0.00\end{array}$ \\
\hline
\end{tabular}

*: BDL: below detection limit

\subsection{Electrochemical corrosion testing}

To determine the required time for the electrical stabilization of the Pt-pseudo-RE vs the Pt-CE the potential of the electrodes immersed in the molten salts was recorded with time. Figure 6 shows that the stabilization time in a chloride molten salt was around 45 minutes as reported by the literature [10-14]. After each corrosion test the chemical stability of these electrodes was evaluated using visual observations. The electrodes did not chemically react with the tested molten salts. 


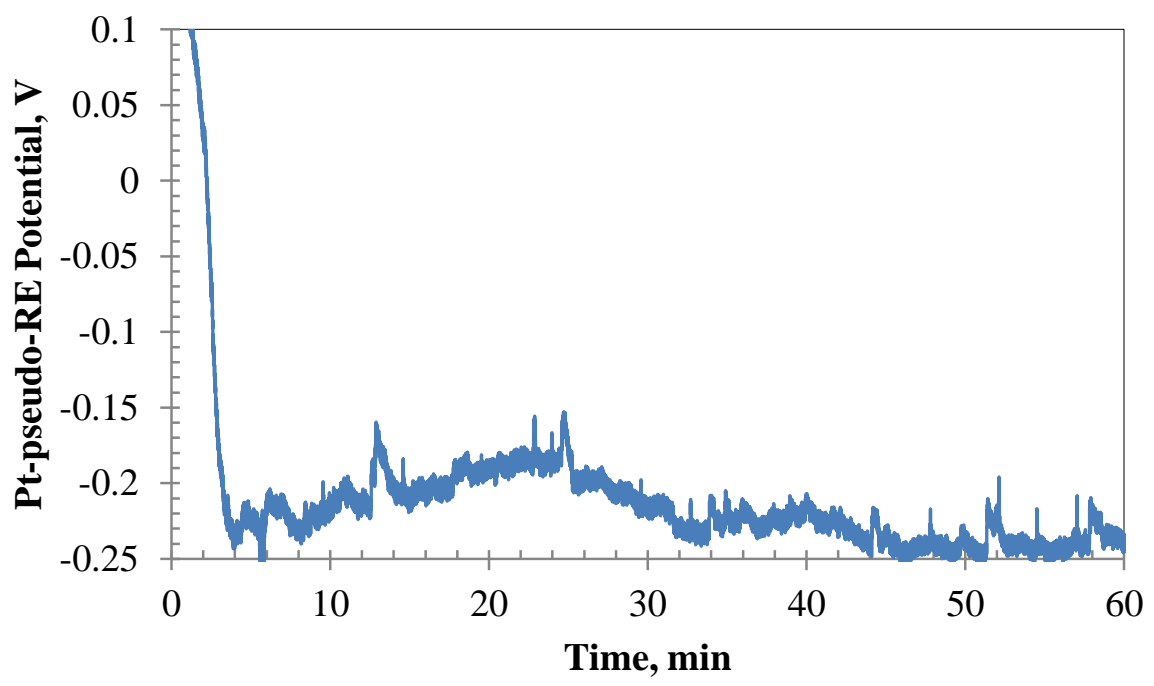

Fig. 6. Potential stabilization of the Pt-pseudo-RE vs. Pt-CE in the molten eutectic 34.42 wt.\% $\mathrm{NaCl}-65.58$ wt. $\% \mathrm{LiCl}$ at $650^{\circ} \mathrm{C}$ under UHP nitrogen.

To test the permeability of the best-performing cement (Aremco 645-N), different configurations were employed to block the porosity of the cements. The encapsulation configurations of the metal cylinders are shown in Table 7. Zero (0) means that no encapsulation was employed and the bare SS347 alloy was evaluated to determine the corrosion baseline. Encapsulation "A" was using only cement Aremco 645-N to partially encapsulate the alloy (see Fig. 5). Encapsulation "B" employed also partial encapsulation of the alloy with Aremco 645-N and a film of BN on top of the cement to block the porosity. Encapsulation " $\mathrm{C}$ " employed only a film of BN on the sides of SS347 leaving the bottom uncovered (similar to Fig. 5) for corrosion evaluations. Encapsulation "D" used the same approach as Encapsulation "B" but the alloy was fully encapsulated. This later configuration was to determine if the porosity was completely blocked and the alloy was able to be protected by the attack of the molten salt.

Table 7. Encapsulation configurations of the metal cylinders.

\begin{tabular}{cl}
\hline Encapsulation & \multicolumn{1}{c}{ Configuration } \\
\hline 0 & none/bare \\
A & Aremco 645-N \\
B & BN film on top of Aremco 645-N \\
C & BN film on metallic surface \\
D & Full encapsulation using approach B \\
\hline
\end{tabular}


The PPS plots of SS347 bare and encapsulated (with only Aremco 645-N) in molten eutectic $\mathrm{NaLi}-\mathrm{Cl}$ at $650^{\circ} \mathrm{C}$ are provided in Figure 7. Table 8 shows the corrosion rates of the bare and encapsulated SS347 using equation 1 and the corrosion current obtained from the interception of the cathodic and anodic Tafles slopes from the PPS curves. Those encapsulations that clearly reported results off from the expected ones (bare alloy) are reported as a single value. The tests that reported corrosion rates close to those of the bare alloy were tested twice to determine repeatability.

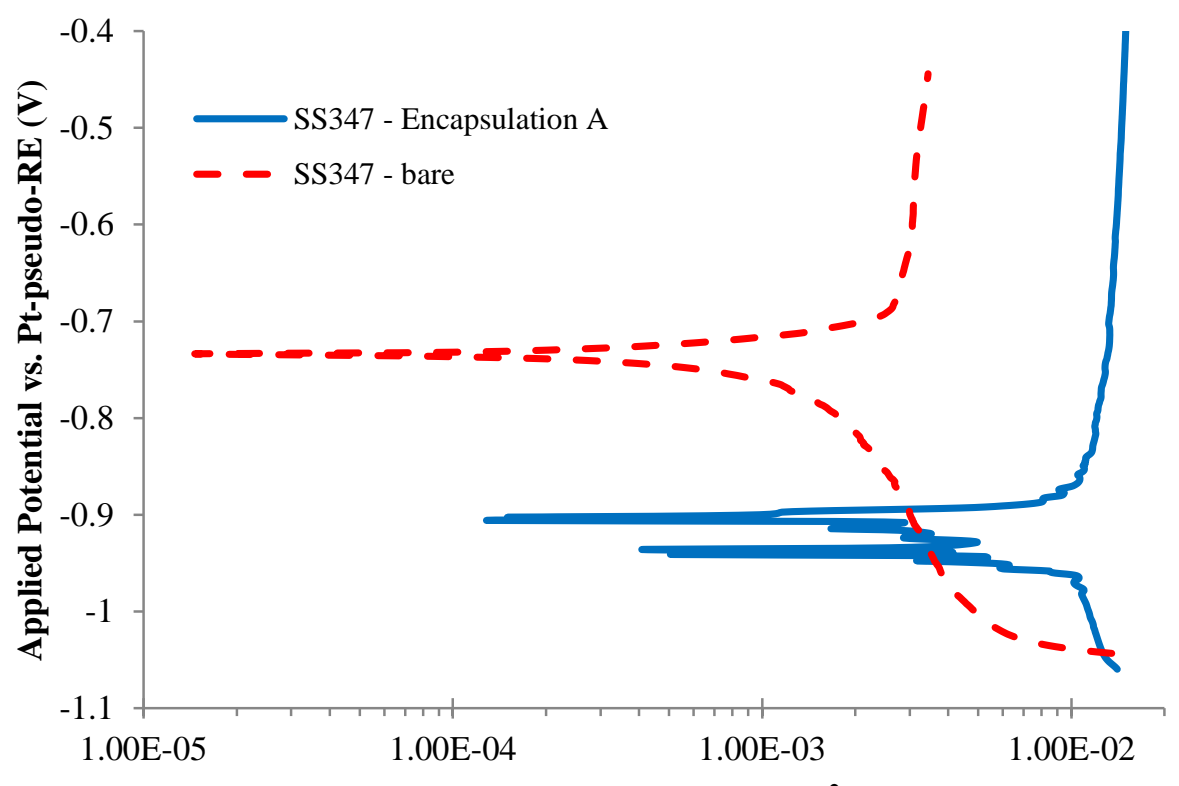

Current Density, $I\left(\mathrm{~A} / \mathrm{cm}^{2}\right)$

Fig. 7. Potentiodynamic polarization sweep of SS347 bare and encapsulated with Aremco 645-N (encapsulation A) in molten eutectic $34.42 \mathrm{wt} . \% \mathrm{NaCl}-65.58 \mathrm{wt} \% \mathrm{LiCl}$ at $650^{\circ} \mathrm{C}$.

Table 8. Corrosion rates (CR) of bare and encapsulated SS347 in eutectic $\mathrm{NaCl}-65.58 \mathrm{wt} \%$ $\mathrm{LiCl}$ at $650^{\circ} \mathrm{C}$. $I_{\text {corr: }}$ corrosion current density.

\begin{tabular}{lccc}
\hline Encapsulation & $\begin{array}{c}\text { Exposed } \\
\text { metallic } \\
\text { area, } \\
\mathbf{c m}^{2}\end{array}$ & $\begin{array}{c}\mathbf{I}_{\text {corr, }} \\
\mathbf{m A} / \mathbf{c m}^{2}\end{array}$ & $\begin{array}{c}\text { CR Alloy, } \\
\mathbf{m m} / \mathbf{y e a r}\end{array}$ \\
\hline $0-$ none/bare & 1.80 & $0.73 \pm 0.03$ & $7.72 \pm 0.32$ \\
$\mathrm{~A}-$ Aremco 645-N & 0.51 & 8.54 & 21.35 \\
B - BN on top of & 0.51 & $0.69 \pm 0.06$ & $7.26 \pm 0.60$ \\
$\begin{array}{c}\text { Aremco 645-N } \\
\text { C - BN films on metallic } \\
\text { surface }\end{array}$ & 0.51 & 0.93 & 9.82 \\
$\begin{array}{c}\text { D - Full encapsulation } \\
\text { using approach B }\end{array}$ & 0 & $8.94 \mathrm{E}-05$ & $9 \mathrm{E}-04$ \\
\hline
\end{tabular}


It is clear that the porosity of the cement is allowing the molten salt to permeate and corrode a larger metallic area than the non-encapsulated area, which was used for the corrosion rate calculations. The corrosion rate of samples encapsulated with only Aremco 645-N cement (Encapsulation " $\mathrm{A}$ ") is three times larger than the results for bare alloys.

BN was used to block the porosity of Aremco $645-\mathrm{N}$. BN was also employed alone to determine its efficiency without the cement. Figure 8 shows the PPS curves for SS347 encapsulated using different configurations of Aremco cement and BN spray.

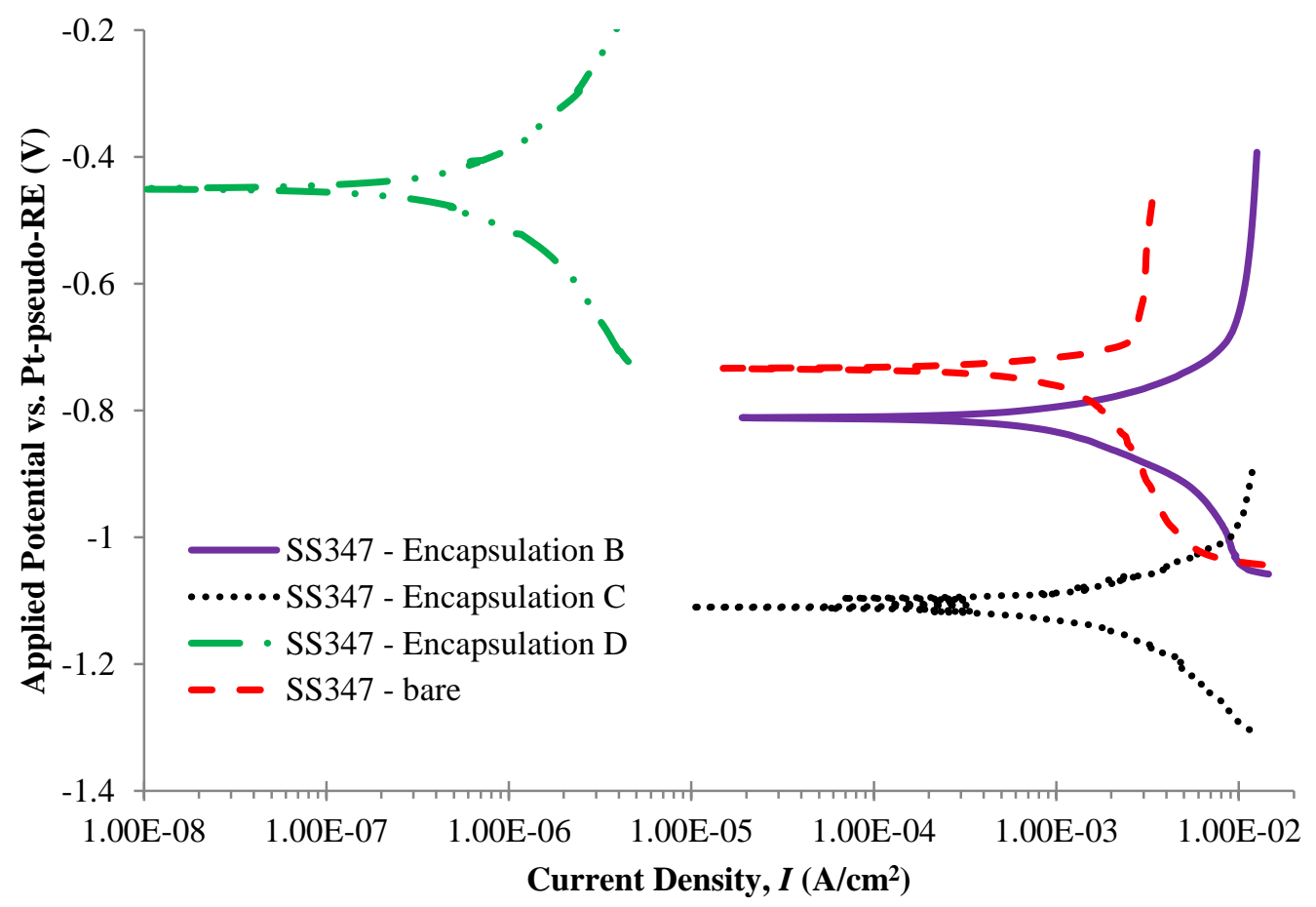

Fig. 8. Potentiodynamic polarization sweep of alloy SS347 bare and with different encapsulations in molten eutectic $34.42 \mathrm{wt} . \% \mathrm{NaCl}-65.58 \mathrm{wt} \% \mathrm{LiCl}$ at $650^{\circ} \mathrm{C}$.

$\mathrm{BN}$ films on top of the metallic surface (Encapsulation " $\mathrm{C}$ ") were not enough to protect the metal surface. Poor adherence between the BN and the metallic surface was observed after the test. When BN spray was used on top of the cement (Encapsulation "B"), similar corrosion rates were obtained to those of the bare alloy $(7.26 \pm 0.60$ and $7.72 \pm 0.32 \mathrm{~mm} /$ year, respectively). It is concluded that the cement porosity was significantly reduced on the encapsulated test samples and thus the molten chlorides were not able to permeate through the cement and corrode the metal surfaces. This encapsulation configuration is believed to be the best out of all of the configurations tested. To verify the efficiency of configuration "B", a full encapsulation of the 
alloy was performed (Encapsulation "D"). It was clear that the OCP showed an open circuit configuration in which no electrical contact was allowed (salt did not reach any metal surface). After eight hours of immersion time, the system showed a very low amount of current after the polarization. This immersion time was to allow permeation of the molten salt through the pores of the cement. Figure 8 shows a reduction of several orders of magnitude in the corrosion current. It was confirmed, after assuming an immersion area similar to the one used in the bare alloy configuration, that the corrosion rate was very low (9E-04 mm/year).

\subsection{Thermodynamic modeling of degradation}

Possible reactions between the components of Aremco 645-N (Table 2), $\mathrm{NaCl}$, and $\mathrm{LiCl}$ were identified using the "Equilibrium Compositions" module of the HSC software. Silica and magnesium phosphate showed to be stable in $\mathrm{NaCl}-\mathrm{LiCl}$. Figure 9 shows the equilibrium composition of stable phases at the low concentration level (below 10 mol.\%). With increasing temperature, zirconium silicate will gradually decompose to form zirconia $\left(\mathrm{ZrO}_{2}\right)$. Magnesium oxide is not stable and it will decompose to form $\mathrm{MgCl}_{2}$ and $\mathrm{MgSiO}_{3}$. Elemental magnesium obtained in ICP-MS corroborates this thermodynamic analysis.

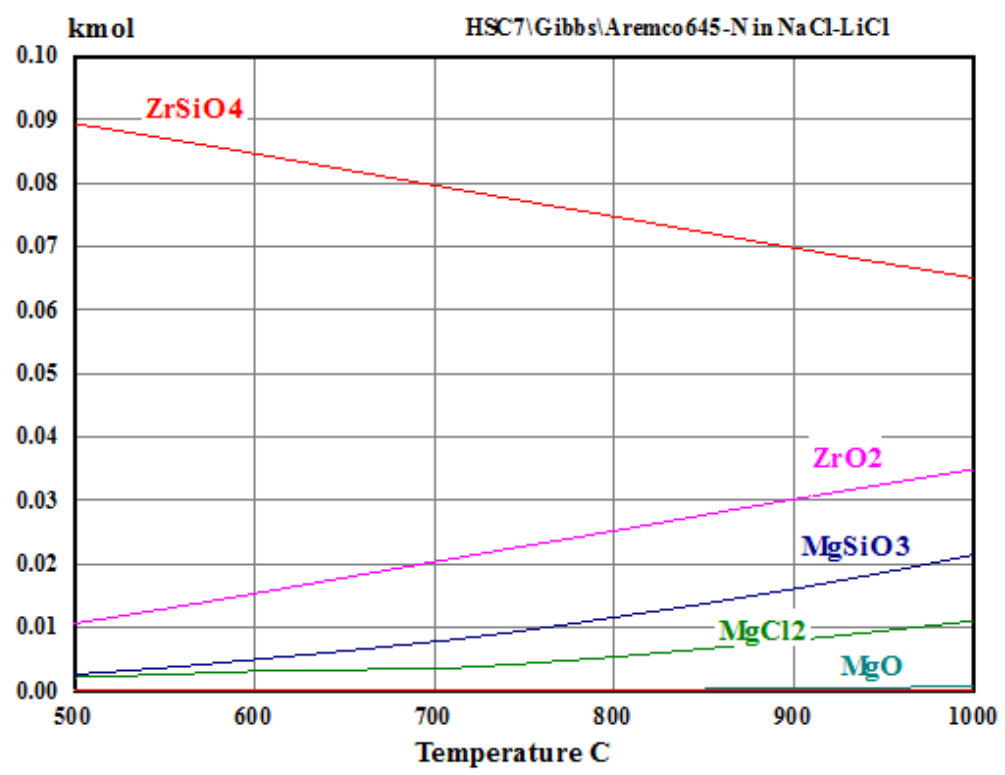

Fig. 9. Chemical equilibria of Aremco 645-N components (Table 1) with molten $\mathrm{NaCl}$ and $\mathrm{LiCl}$. BN showed to be chemically stable in molten $\mathrm{NaCl}-\mathrm{LiCl}$. The dissolved elemental boron obtained from ICP-MS probably came from small particles detached from the deposited BN film, which were then dissolved in the $\mathrm{HCl}$ used to completely digest the sample for ICP analysis. 


\section{Conclusions}

Silica-based castable cements are capable of protecting containment metallic alloys from the attack of molten chlorides at high temperatures $\left(650^{\circ} \mathrm{C}\right)$ in short term tests. $\mathrm{BN}$ is required to block the porosity of the cement (after curing) in order to prevent permeation of the molten chloride towards the metal surface. Molten eutectic $34.42 \mathrm{wt} \% \mathrm{NaCl}-65.58 \mathrm{wt} \% \mathrm{LiCl}$ is a good advanced high-temperature HTF and TES material candidate for CSP applications but it is very corrosive to metallic components. SS347 had a corrosion rate of $7.72 \pm 0.32 \mathrm{~mm} /$ year at $650^{\circ} \mathrm{C}$ in this molten chloride system. Metallic components could be protected using castable cements as the ones identified here. Further long-term degradation tests of the cements are required to determine the chemical stability of the best configuration determined in this investigation (Aremco 645-N with $\mathrm{BN}$ to block porosity). The proposed corrosion mitigation approach using castable cements to protect metallic surfaces could be implemented to protect tank walls. This technology is well known in the repair of refractory materials for blast furnace lining. The methods used are grouting lining, cold spray technology, furnace shell hole opening technology using guns gunning, and remote control gunning technology [20,21]. The implementation of internal pipes with small diameter will require further evaluation to determine if the approach is viable.

\section{Acknowledgments}

The work at NREL was financially supported by the U.S. Department of Energy under Contract No. DE-AC36-08-GO28308.

\section{References}

1. US Department of Energy, SunShot Concentrating Solar Power Program, http://www1.eere.energy.gov/solar/pdfs/sunshot_csp_poster.pdf (accessed on July 1, 2015).

2. T. Faraz, Benefits of concentrating solar power over solar photovoltaic for power generation in Bangladesh, $2^{\text {nd }}$ International Conference on the Developments in Renewable Energy Technology (2012).

3. S. Kuravi, J. Trahan, D. Goswani, M. Rahman, and E. Stefanakos, Thermal energy storage technologies and systems for concentrating solar power plants, Progress in Energy and Combustion Science 39 (2013) 296-300. 
4. N. Calvet, J. C. Gomez, A. Faik, V. V. Roddatis, A. Meffre, G. C. Glatzmaier, S. Doppiu, X. Py, Compatibility of a post-industrial ceramic with nitrate molten salts for use as filler material in a thermocline storage system, Applied Energy 109 (2013) 387-393.

5. S. Guillot, A. Faik, A. Rakhmatullin, J. Lambert, E. Veron, P. Echegut, C. Bessada, N. Calvet, X. Py, Corrosion effects between molten salts and thermal storage material for concentrated solar power plants, Applied Energy, 94 (2012) 174-181.

6. Soo-Haeng Cho, Byung-Heong Park, Jin-Mok Hur, Han-Soo Lee, Kee-Chan Song, JongHyeon Lee, Corrosion behaviour of $\mathrm{Y}_{2} \mathrm{O}_{3}-\mathrm{ZrO}_{2}$ coatings on IN713 $\mathrm{LC}$ in a $\mathrm{LiCl}-\mathrm{Li}_{2} \mathrm{O}$ molten salt, Corrosion Science, 52 (2010) 2353-2364.

7. M. Takeuchi, T. Kato, K. Hanada, T. Koizumi, S. Aose, Corrosion resistance of ceramic materials in pyrochemical reprocessing condition by using molten salt for spent nuclear oxide fuel, Journal of Physics and Chemistry of Solids, 66 (2005) 521-525.

8. V. Vitry, A-F. Kanta, F. Delaunois, Application of nitriding to electroless nickel-boron coatings: Chemical and structural effects; mechanical characterization; corrosion resistance, Materials \& Design, 39 (2012) 269-278.

9. M. Ürgen, A.F. Çakir, O.L. Eryilmaz, C. Mitterer, Corrosion of zirconium boride and zirconium boron nitride coated steels, Surface and Coatings Technology, 71 (1995) 60-66.

10. J. I. Barraza-Fierro, M. A. Espinosa-Medina, M. Hernandez-Hernandez, H. B. Liu, and E. Sosa-Hernandez, Effect of $\mathrm{Li}$ and $\mathrm{Cu}$ addition on corrosion of $\mathrm{Fe}-40$ at.\% Al intermetallics in molten LiCl-KCl eutectic salt, Corrosion Science 59 (2012) 119-126

11. J.G. Gonzalez-Rodriguez, A. Luna-Ramirez, M. Salazar, J. Porcayo-Calderon, G. Rosas, A. Martinez-Villafane, Molten salt corrosion resistance of $\mathrm{FeAl}$ alloy with additions of $\mathrm{Li}, \mathrm{Ce}$ and Ni, Mat. Sci. Eng., A399 (2005) 344-350.

12. C. Cuevas-Arteaga, J. Uruchurtu-Chavarin, J. Porcayo-Calderon, G. Izquierdo-Montalvo, and J. Gonzalez, Study of molten salt corrosion of HK-40m alloy applying linear polarization resistance and conventional weight loss techniques, Corrosion Science 46 (2004) 2663-2679.

13. M.A. Espinosa, G. Carbajal de la Torre, J. Porcayo-Calderon, M. Martinez-Villafañe, J.G. Chacon-Nava, M. Casales, J.G. Gonzalez-Rodriguez, Corrosion of atomized Fe40Al based intermetallics in molten $\mathrm{Na}_{2} \mathrm{SO}_{4}$, Materials and Corrosion, 54 (2003) 304-310. 
14. M. A. Espinosa-Medina, G. Carbajal-De la Torre, H. B. Liu, A. Martínez-Villafañe, and J. G. González-Rodriguez, Hot corrosion behaviour of $\mathrm{Fe}-\mathrm{Al}$ based intermetallic in molten $\mathrm{NaVO}_{3}$ salt, Corrosion Science 51 (2009) 1420-1427.

15. J. Porcayo-Calderon, O. Sotelo-Mazon, V. M. Salinas-Bravo, C. D. Arrieta-Gonzalez, J. J. Ramos-Hernandez, and C. Cuevas-Arteaga, Electrochemical performance of Ni20Cr coatings applied by combustion powder spray in $\mathrm{ZnCl}_{2}-\mathrm{KCl}$ molten salts, Int. J. Electrochem. Sci., 7 (2012) 1134-1148.

16. R. A. Rapp and Y. S. Zhang, Hot corrosion of materials: Fundamental studies, Journal of Metals 46 (1994) 47-55.

17. Gamry Instruments, Getting Started with Electrochemical Corrosion Measurements, (2011).

18. J.G. Gonzalez-Rodriguez, E. Mejia, M.A. Lucio-Garcia, V.M. Salinas-Bravo, J. PorcayoCalderon, A. Martinez-Villafañe, An electrochemical study of the effect of Li on the corrosion behavior of $\mathrm{Ni}_{3} \mathrm{Al}$ intermetallic alloy in molten $(\mathrm{Li}+\mathrm{K})$ carbonate, Corrosion Science, 51 (2009) 1619-1627.

19. HSC Chemistry Software Version 7.11, Outotec. Research Center, (2013).

20. http://www.calderys.com/refractory-focus/blast-furnace-design-balst-furnacemaintenance.html (checked on December 31, 2015).

21. J. Gerber, J. E. Bogan, S. B. Bonsall, Dry process gunning of refractory castable, US 5976632 A, Nov 2, 1999.] 


\section{Tables' captions}

\section{Table 1}

Eutectic composition in mass percentage (wt.\%) of the molten salts. Melting/eutectic temperature $\left(\mathrm{T}_{\mathrm{e}}\right)$ and tested temperatures $\left(\mathrm{T}_{\mathrm{t}}\right)$.

\section{Table 2}

Chemical composition of castable ceramic refractory cements provided by the supplier.

\section{Table 3}

Parameters of the cement curing process (provided by Sauereisen Corporation).

\section{Table 4}

Paints and aerosol chemical compositions.

\section{Table 5}

Elemental composition of stainless steel 347 (SS347).

\section{Table 6}

ICP-MS chemical analysis of dissolved elements from refractory cement (silica base sprayed with $\mathrm{BN}$ ) in $124 \mathrm{~g}$ of eutectic $\mathrm{NaCl}-\mathrm{LiCl}$ at $650^{\circ} \mathrm{C}$ for two hours. Results are normalized to exposed area. Values are reported as average and standard deviation for three sets of data.

\section{Table 7}

Encapsulation configurations of the metal cylinders.

\section{Table 8}

Corrosion rates (CR) of bare and encapsulated SS347 in eutectic $\mathrm{NaCl}-65.58 \mathrm{wt} \% \mathrm{LiCl}$ at $650^{\circ} \mathrm{C}$. jorr: corrosion current density. 


\section{Figures' captions}

Fig. 1. Consolidated piece of cured refractory cement employed for chemical testing.

Fig. 2. Molten salt corrosion electrochemical system with the off-gas treatment.

Fig. 3. Scheme showing the procedure to calculate Icorr and Tafel slopes [18].

Fig. 4. (a) Drawing of the electrochemical cell with the three-electrode arrangement. 1: stainless steel 316 chamber with quartz lining; 2: working electrode or sample electrical connector; 3: Pt-pseudo reference electrode (RE); 4: platinum counter electrode (CE); 5: alumina crucible containing molten salts; 6: encapsulated sample or working electrode (WE), and (b) Picture of the three-electrode arrangement (left to right: $\mathrm{CE}, \mathrm{WE}$, and RE).

Fig. 5. Encapsulated stainless steel 347 (SS347) cylinder.

Fig. 6. Potential stabilization of the Pt-pseudo-RE vs. Pt-CE in the molten eutectic 34.42 wt.\% $\mathrm{NaCl}-65.58 \mathrm{wt} . \% \mathrm{LiCl}$ at $650^{\circ} \mathrm{C}$ under UHP nitrogen.

Fig. 7. Potentiodynamic polarization sweep of SS347 bare and encapsulated with Aremco 645-N (encapsulation A) in molten eutectic $\mathrm{NaCl}-65.58 \mathrm{wt} \% \mathrm{LiCl}$ at $650^{\circ} \mathrm{C}$.

Fig. 8. Potentiodynamic polarization sweep of alloy SS347 bare and with different encapsulations in molten eutectic $\mathrm{NaCl}-65.58 \mathrm{wt} \% \mathrm{LiCl}$ at $650^{\circ} \mathrm{C}$.

Fig. 9. Chemical equilibria of Aremco 645-N components (Table 1) with molten $\mathrm{NaCl}$ and $\mathrm{LiCl}$. 
Table 1

\begin{tabular}{llcc}
\hline \multicolumn{1}{c}{ Name } & \multicolumn{1}{c}{ Composition, wt.\% } & $\begin{array}{c}\mathbf{T}_{\mathbf{e}}, \\
{ }^{\circ} \mathbf{C}\end{array}$ & $\begin{array}{c}\mathbf{T}_{\mathbf{t}}, \\
{ }^{\circ} \mathbf{C}\end{array}$ \\
\hline $\mathrm{KNaLi}_{-} \mathrm{CO}_{3}$ & $\mathrm{~K}_{2} \mathrm{CO}_{3}-33.39 \mathrm{wt} \% \mathrm{Na}_{2} \mathrm{CO}_{3}$ & 398 & 600 \\
$\mathrm{KNa} \mathrm{CO}_{3}$ & $-32.14 \mathrm{wt} \% \mathrm{Li}_{2} \mathrm{CO}_{3}$ & & \\
$\mathrm{~K}_{2} \mathrm{CO}_{3}-53.82 \mathrm{wt} \% \mathrm{Na}_{2} \mathrm{CO}_{3}$ & 709 & 750 \\
$\mathrm{NaLi}-\mathrm{Cl}$ & $\mathrm{NaCl}-65.58 \mathrm{wt} \% \mathrm{LiCl}$ & 554 & 650 \\
$\mathrm{NaK}-\mathrm{Cl}$ & $\mathrm{NaCl}-55.47 \mathrm{wt} \% \mathrm{KCl}$ & 657 & 700 \\
\hline
\end{tabular}


Table 2

\begin{tabular}{cl}
\hline Cement & \multicolumn{1}{c}{ Composition, wt.\% } \\
\hline & Fused silica: 40 -75 \\
Aremco & Magnesium phosphate mono basic: $5-20$ \\
$645-\mathrm{N}$ & Zirconium silicate: $5-10$ \\
& Magnesium oxide: $5-20$ \\
& Silica crystalline: $<0.5$ \\
\hline & Zirconium silicate: $<68-78$ \\
Sauereisen & Magnesium phosphate mono basic: $<11-18$ \\
$\# 8$ & Magnesium oxide: $<10-15$ \\
& Boric acid: $<2$ \\
& Silica crystalline: $<1$ \\
\hline \multirow{2}{*}{ Sauereisen } & Silica crystalline: $<90$ \\
$\# 31$ & Sodium silica fluoride $<15$ \\
& Clay: $<5$ \\
\hline Sauereisen & Silica crystalline $<80$ \\
$\# 76$ & Calcium aluminate $<40$ \\
\hline
\end{tabular}


Table 3

\begin{tabular}{cc}
\hline Time, hours & Temperature, ${ }^{\circ} \mathbf{C}$ \\
\hline $18-24$ & room temperature \\
$8-12$ & 66 \\
4 & 82 \\
4 & 93 \\
4 & 105 \\
4 & 121 \\
$38^{\circ} \mathrm{C} / \mathrm{h}$ & up to the testing \\
& temperature \\
\hline
\end{tabular}


Table 4

\begin{tabular}{|c|c|c|}
\hline $\begin{array}{l}\text { Product } \\
\text { Name }\end{array}$ & $\begin{array}{l}\text { Company } \\
\text { Name }\end{array}$ & Composition, wt.\% \\
\hline $\mathrm{BN}$ aerosol & $\begin{array}{c}\text { ZYP } \\
\text { Coatings, } \\
\text { Inc. }\end{array}$ & $\begin{array}{l}\text { BN: } 15-20 \\
\text { Ethanol: } 15-20 \\
\text { 2-Propanone: } 30-35 \\
\text { Propane: } 10-15 \\
\text { Butane: } 10-15\end{array}$ \\
\hline $\begin{array}{l}\text { Ceramabind } \\
643-1 \text { paint }\end{array}$ & Aremco & $\begin{array}{l}\text { Potassium Silicate: } 30 \\
\text { Water: } 70\end{array}$ \\
\hline BN paint & Aremco & $\begin{array}{l}\text { BN: } 97 \\
\text { Magnesia: } 1 \\
\text { Silica: } 2 \\
\text { Carbon binder for sintering: }<2\end{array}$ \\
\hline
\end{tabular}


Table 5

Elemental Composition, wt.\%

\begin{tabular}{ccccccc}
$\mathbf{F e}$ & $\mathbf{N i}$ & $\mathbf{C r}$ & $\mathbf{C o}$ & $\mathbf{M n}$ & $\mathbf{S i}$ & $\mathbf{C}$ \\
\hline$\sim 70.03$ & 9.62 & 17.67 & 0.2 & 1.66 & 0.77 & 0.051 \\
\hline
\end{tabular}


Table 6

\begin{tabular}{ccccccccccccc}
\hline Elements & Al & $\mathbf{B}$ & $\mathbf{C a}$ & $\mathbf{C o}$ & $\mathbf{C r}$ & $\mathbf{C u}$ & $\mathbf{F e}$ & $\mathbf{M g}$ & $\mathbf{M n}$ & $\mathbf{M o}$ & $\mathbf{N i}$ & $\mathbf{V}$ \\
\hline Normalized & 0.07 & 1.00 & $\mathrm{BDL}$ & 0.09 & 0.08 & 0.22 & 0.27 & 3.61 & 0.10 & $\mathrm{BDL}$ & $\mathrm{BDL}$ & $0.07 \pm$ \\
Composition & \pm & \pm & $*$ & \pm & \pm & \pm & \pm & \pm & \pm & $*$ & $*$ & 0.00 \\
$\left(\mathbf{p p m} / \mathbf{c m}^{2}\right)$ & 0.00 & 0.01 & & 0.00 & 0.00 & 0.01 & 0.00 & 0.05 & 0.00 & & & \\
\hline
\end{tabular}

*: BDL: below detection limit 
Table 7

\begin{tabular}{cl}
\hline Encapsulation & \multicolumn{1}{c}{ Configuration } \\
\hline 0 & none/bare \\
A & Aremco 645-N \\
B & BN film on top of Aremco 645-N \\
C & BN film on metallic surface \\
D & Full encapsulation using approach B \\
\hline
\end{tabular}


Table 8

\begin{tabular}{|c|c|c|c|}
\hline Encapsulation & $\begin{array}{c}\text { Exposed } \\
\text { metallic } \\
\text { area, } \\
\mathrm{cm}^{2}\end{array}$ & $\begin{array}{c}I_{\text {corr }} \\
\mathbf{m A} / \mathbf{c m}^{2}\end{array}$ & $\begin{array}{l}\text { CR Alloy, } \\
\text { mm/year }\end{array}$ \\
\hline 0 - none/bare & 1.80 & $0.73 \pm 0.03$ & $7.72 \pm 0.32$ \\
\hline$A-$ Aremco $645-\mathrm{N}$ & 0.51 & 8.54 & 21.35 \\
\hline $\begin{array}{l}\mathrm{B}-\mathrm{BN} \text { on top of } \\
\text { Aremco } 645-\mathrm{N}\end{array}$ & 0.51 & $0.69 \pm 0.06$ & $7.26 \pm 0.60$ \\
\hline $\begin{array}{l}\mathrm{C}-\mathrm{BN} \text { films on metallic } \\
\text { surface }\end{array}$ & 0.51 & 0.93 & 9.82 \\
\hline $\begin{array}{c}\text { D - Full encapsulation } \\
\text { using approach B }\end{array}$ & 0 & 8.94E-05 & 0.0009 \\
\hline
\end{tabular}


Fig. 1

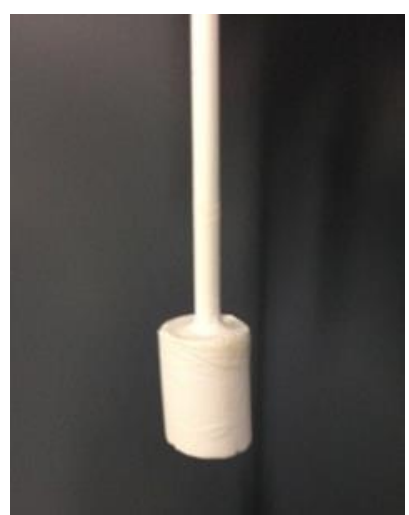


Fig. 2.

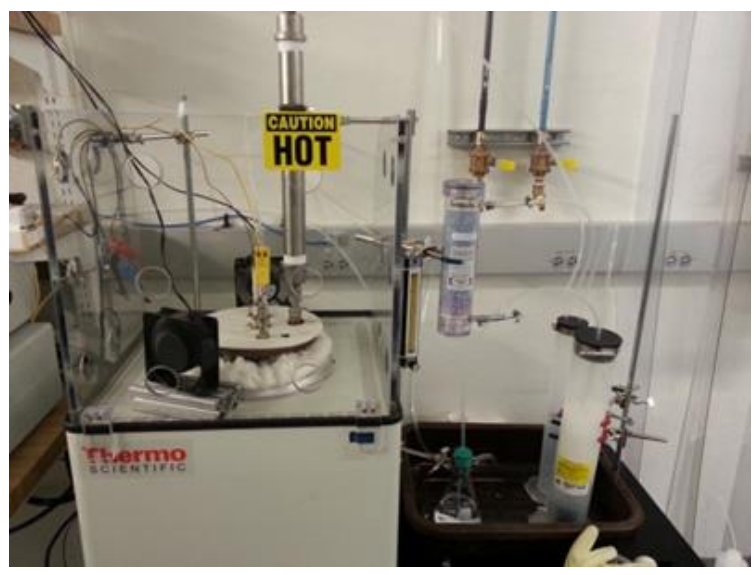


Fig. 3.

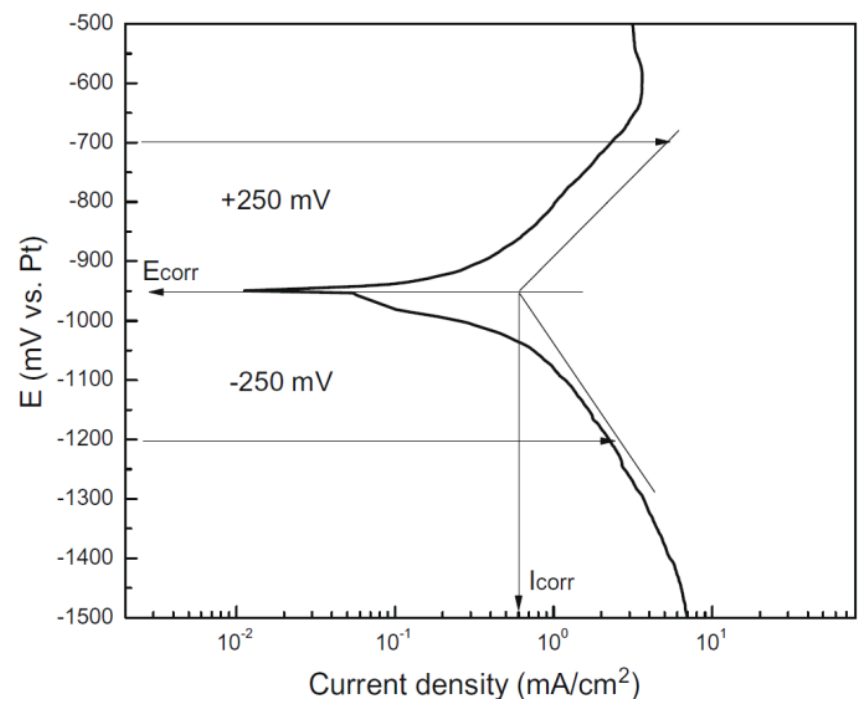


Fig. 4(a)

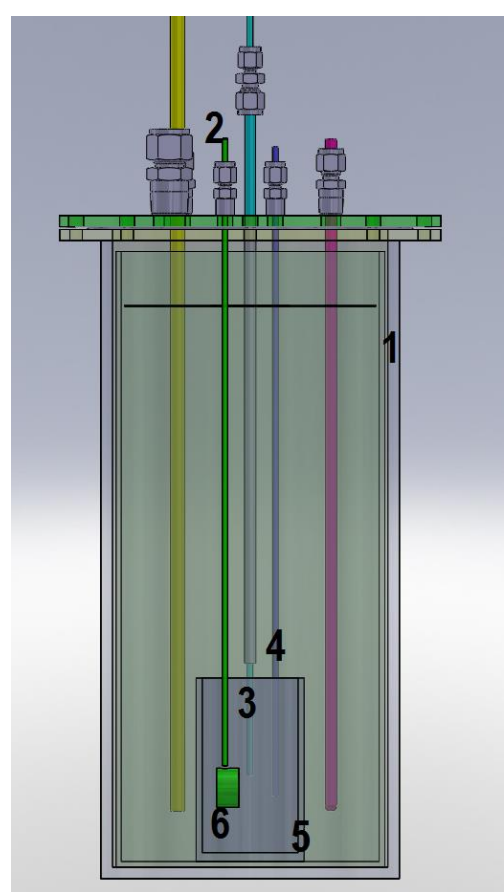


Fig. 4(b)

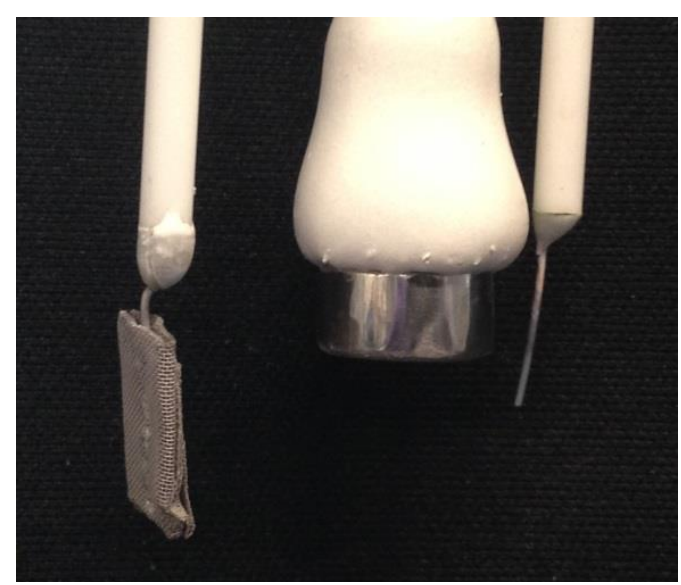


Fig. 5.

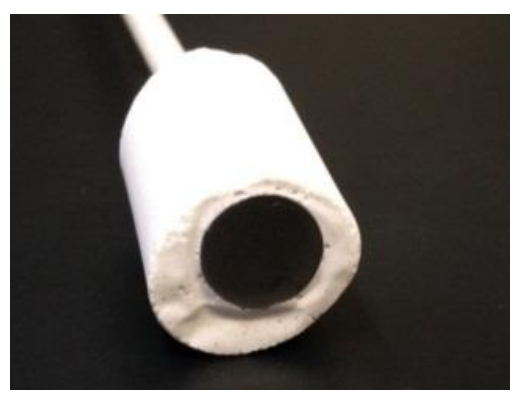


Fig. 6.

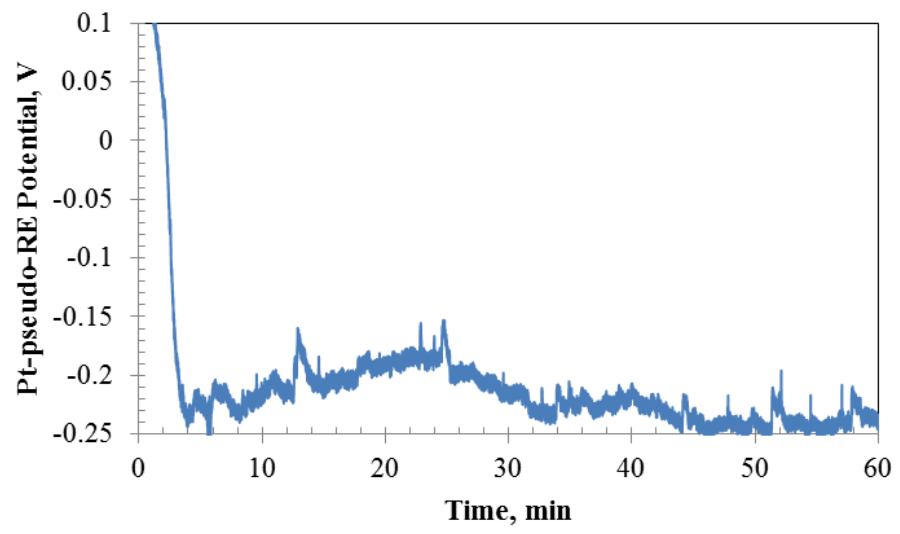


Fig. 7.

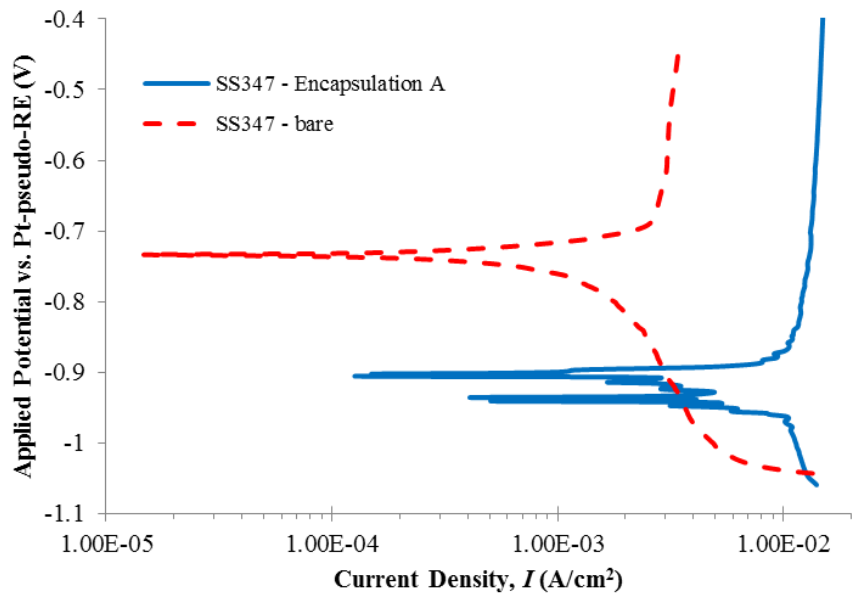


Fig. 8.

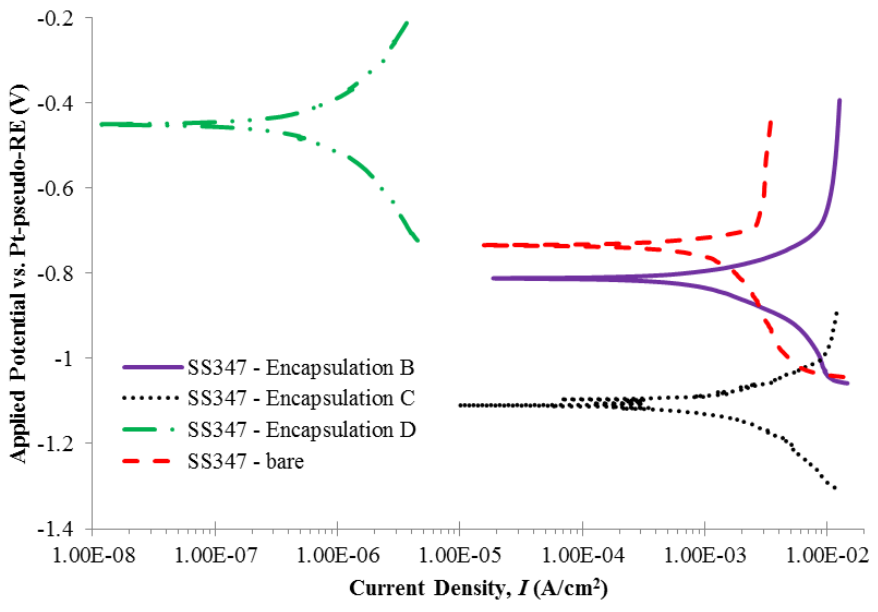


Fig.9.

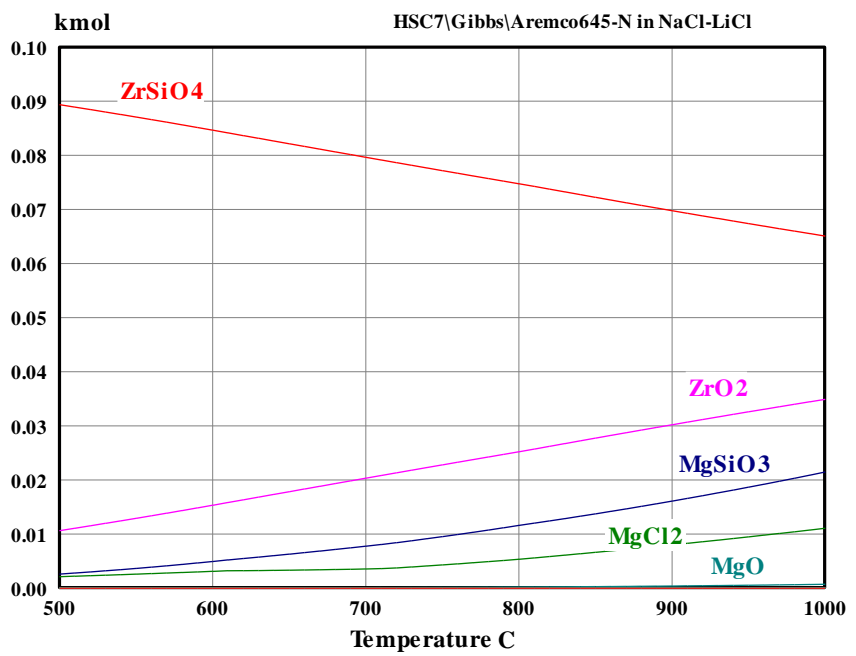

